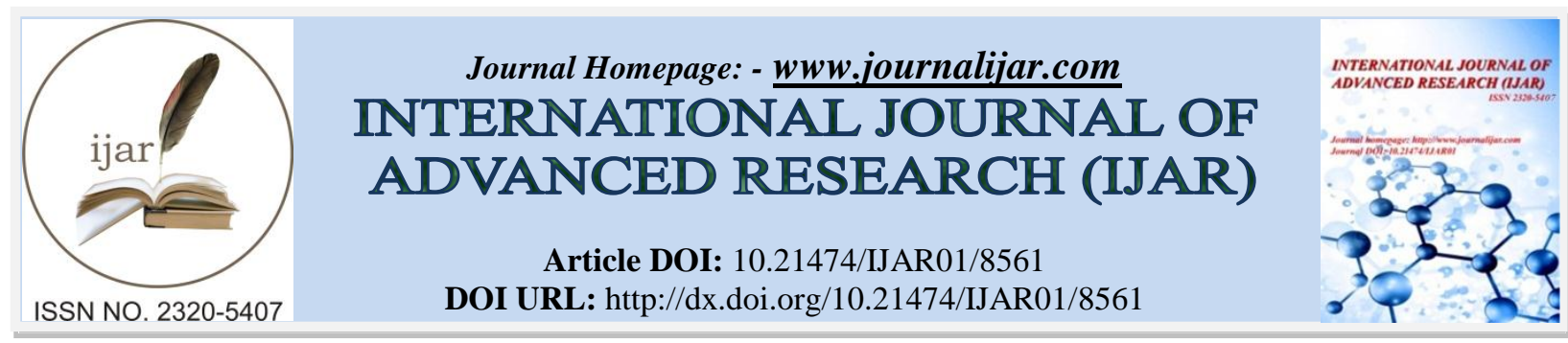

RESEARCH ARTICLE

\title{
CATALYTIC CRACKING OF TOLUENE USING RED MUD: HYDROGEN EVOLUTION AND CARBON FORMATION.
}

Nidhi Gupta $^{1}$, Malini Balakrishnan ${ }^{1,2}$, Justin S. J. Hargreaves ${ }^{3}$, Ian Pulford ${ }^{3}$ and Vidya S Batra ${ }^{1}$

1. TERI School of Advanced Studies, Plot No. 10 Institutional Area, Vasant Kunj, New Delhi - 110070, India.

2. The Energy and Resources Institute, India Habitat Centre, Lodi Road, New Delhi 110003, India.

3. WestCHEM, School of Chemistry, University of Glasgow, Glasgow G12 8QQ, UK.

\section{Manuscript Info}

\section{Manuscript History}

Received: 14 December 2018

Final Accepted: 16 January 2019

Published: February 2019

Key words:-

red mud; toluene; hydrogen; nano carbon; graphite; catalyst.

\begin{abstract}
Toluene has been used as a model tar compound in many cracking and reforming studies in the context of biomass gasification and pyrolysis. Low cost alternate catalysts such as biochar, limonite have been studied. Toluene has also been used in chemical vapour deposition of carbon nano tubes. In this study, red mud waste from the aluminium industry without any pre treatment was used as a catalyst for toluene cracking. The hydrogen evolution and nano carbon formation were studied. The reduction behaviour of the catalyst in hydrogen showed conversion of iron hydroxide and oxide to iron above $700{ }^{\circ} \mathrm{C}$. Hydrogen formation rate was maximum at $800{ }^{\circ} \mathrm{C}$ after around $7 \mathrm{~h}$ and subsequently reduced with time. Depending on the carbon content, the post reaction catalyst was comprised of reduced iron oxides (magnetite, wustite) and mixture of iron, iron carbide and graphitic carbon. Carbon content up to $46 \%$ was obtained and the deposited carbon was in the form of nano fibers. While red mud has been used in catalytic steam gasification and pyrolysis of biomass, the hydrogen evolution using red mud and toluene has not been reported.
\end{abstract}

Copy Right, IJAR, 2019,. All rights reserved.

\section{Introduction:-}

Hydrogen energy is an attractive alternative to fossil fuels and one of the sources is from biomass. One of the limitations of the utilization of biomass in pyrolysis and gasification process is the formation of tar components which are undesired as they lower the overall efficiency of the process and can clog the downstream pipelines (Ni et al., 2006). Thus there is a need for catalyst which can breakdown the tar to the useful components. One potential candidate is red mud which is a waste from the aluminium industry and has disposal issues.

Several reviews have covered the catalytic removal of tar from biomass gasification or pyrolysis (Abu El-Rub et al., 2006; Han et al., 2008; Rios et al., 2018; Shen et al., 2013; Xu et al., 2010). The main catalysts are Ni based, transition metal based, zeolites, char, natural materials or alkali metal based. Ni based catalyst are active but undergo deactivation due to carbon deposition. Noble ( $\mathrm{Rh}, \mathrm{Ru}, \mathrm{Pd}, \mathrm{Pt})$ and non-noble $(\mathrm{Co}, \mathrm{Fe}, \mathrm{Zn}$, and $\mathrm{Cu}$ ) transition metal catalysts have been studied in steam reforming of tar. Naturally occurring dolomite or olivine have been used in the existing form or after some treatment. Zeolites and activated carbon/char have been tested as catalysts and as catalyst supports. 
Toluene has been studied as a model tar compound in cracking and reforming reactions. Nickel based catalysts are commonly used but there are also reports of alternate catalyst that are inexpensive and active (Gerber 2007). Natural limonite (Zou et al., 2016), biomass derived char (Li et al., 2016), iron supported biochar (Kastner et al., 2015), sewage sludge char (Lu et al., 2016) have been reported. In these studies, toluene conversion was observed at temperatures above $750{ }^{\circ} \mathrm{C}$.

Nano carbons obtained through cracking of hydrocarbons have various applications such as sorbents, catalysts, catalyst supports and fillers of electro-conductive plastics etc. (Baughman et al., 2002). Toluene has been used as hydrocarbon source to synthesize carbon nano tubes catalysed by iron compounds by using ferrocene along with toluene (Pinault et al., 2005; Singh et al., 2003a, b). Depending on the processing conditions, different carbon nano tube morphology, purity and properties could be obtained.

We have previously reported the activity of red mud in hydrogen generation and nano carbon formation with different hydrocarbons and have reported preliminary results on post reaction catalyst characteristics after toluene exposure (Alharthi et al., 2016; Balakrishnan et al., 2009). In this study, we examine the hydrogen evolution and nano carbon formation using toluene as the hydrocarbon and red mud as the catalyst.

\section{Experimental procedure:-}

The starting red mud (RM7) was dried and sieved through 150 micron sieve. The characteristics have been reported earlier (Balakrishnan et al., 2009). To understand the reduction behaviour, in-situ X-ray diffraction (XRD) and insitu thermal analysis (TGA) were carried out in an atmosphere of 5\% hydrogen (balance nitrogen). XRD was done using Siemens D5000 diffractometer using $\mathrm{Cu} \mathrm{K} \mathrm{K}_{\alpha}$ radiation with the $2 \theta$ range as $10-80^{\circ}$, with a step size of $0.02^{\circ}$. Thermal analysis was done with TA instruments SDT Q600 instrument with measurements being undertaken in the temperature range from ambient to $1000{ }^{\circ} \mathrm{C}$. The post reaction catalysts were also analyzed by XRD and TGA in air atmosphere under the same conditions. CHN was done by combustion using an Exeter Analytical CE-440 elemental analyzer. Scanning Electron Microscopy was done using XL30 ESEM Phillips microscope operating at $20 \mathrm{kV}$.

Catalytic studies were done in a fixed bed reactor in the temperature range 300 to $800{ }^{\circ} \mathrm{C}$. Nitrogen was used as the carrier gas and was bubbled through toluene maintained at $25{ }^{\circ} \mathrm{C}$ at a flow rate of $100 \mathrm{ml} / \mathrm{min}$. The volume of catalyst taken was $0.5 \mathrm{ml}$, corresponding to a GHSV of $12,000 \mathrm{~h}^{-1}$. The toluene conversion and hydrogen evolution were measured using GC (Nucon 5700) with FID having a chemosorb column and TCD with a carbosphere column. The experiments were done in a heating cycle from $500{ }^{\circ} \mathrm{C}$ to $800{ }^{\circ} \mathrm{C}$ with a hold of $1 \mathrm{~h}$ each at $500{ }^{\circ} \mathrm{C}, 700{ }^{\circ} \mathrm{C}$ and $800{ }^{\circ} \mathrm{C}$. Experiments were also done at $800^{\circ} \mathrm{C}$ for 6.75 and $10 \mathrm{~h}$.

\section{Results and discussions:-}

The starting red mud was comprised of mainly $\mathrm{Fe}_{2} \mathrm{O}_{3}(36.79 \%), \mathrm{Al}_{2} \mathrm{O}_{3}(23.51 \%)$ and $\mathrm{SiO}_{2}(14.60 \%)$ and the phases present were goethite, haematite, quartz and gibbsite (Balakrishnan et al., 2009). Since metallic iron is the catalytically active phase for cracking reactions, the phase changes during reduction were studied. Figure 1 shows the different phases with increasing temperature from $100{ }^{\circ} \mathrm{C}$ to $800{ }^{\circ} \mathrm{C}$ in hydrogen. The in-situ XRD shows reduction in peaks of gibbsite, goethite and their complete removal at $300{ }^{\circ} \mathrm{C}$. At temperatures above $400{ }^{\circ} \mathrm{C}$, haematite peaks were not observed and magnetite peaks were observed in the temperature range $400-700{ }^{\circ} \mathrm{C}$. From 700 to $800{ }^{\circ} \mathrm{C}$, the primary peak was iron. Peaks of wustite were not significant. This is similar to the results obtained in the treatment of red mud in hydrogen where reduction of hematite to magnetite and reduction of magnetite to iron took place in the temperate range $300{ }^{\circ} \mathrm{C}$ to $480{ }^{\circ} \mathrm{C}$ (Samouhos et al., 2017). In a controlled reduction of red mud in hydrogen at different temperatures, reduction to magnetite and further reduction to iron at temperatures of $500{ }^{\circ} \mathrm{C}$ and $600{ }^{\circ} \mathrm{C}$ was observed (Costa 2010).

The in-situ TGA in hydrogen is shown in Figure 2 along with TGA in air. It is observed that till around $500{ }^{\circ} \mathrm{C}$, the behaviour is identical. Beyond this temperature, in a reducing atmosphere, there is further weight loss which continues. This can be attributed to the reduction of iron oxides to iron and matches with the in-situ XRD results.

The toluene conversion and hydrogen evolution at $800{ }^{\circ} \mathrm{C}$ from $6.75 \mathrm{~h}$ run and $10 \mathrm{~h}$ run are shown in Figure 3 . The same in the heating cycle are shown in Figure 4 . At $800^{\circ} \mathrm{C}$, it is observed that a maximum hydrogen evolution rate of $2 \times 10^{-4} \mathrm{~mol} \mathrm{~min}^{-1} \mathrm{~g}^{-1}$ is obtained. The peak value was obtained after around $6 \mathrm{~h}$ and then was reduced. The toluene conversion similarly shows an increase followed by a decrease. In the initial stages it is expected that the 
toluene reacts with iron hydroxides and oxides to form iron following which hydrogen evolution increases. The decrease with time could be due to deactivation from carbon deposition. In a study on toluene cracking with haematite, it was found that the toluene conversion was better at $700{ }^{\circ} \mathrm{C}$ than at $800{ }^{\circ} \mathrm{C}$ and the lowering of performance at $800{ }^{\circ} \mathrm{C}$ was attributed to carbon deposition (Zou et al., 2016). In a test with toluene cracking on sewage char, it was observed that hydrogen content and toluene conversion decreased with time. This was attributed to deposition of coke on the catalyst (Lu et al., 2016).

Study on toluene cracking on biomass char catalyst showed that the main non-condensable gases were hydrogen, methane, carbon monoxide, carbon di-oxide. The hydrogen selectivity considering hydrogen and methane amounts showed more than $90 \%$ hydrogen selectivity at temperatures above $750{ }^{\circ} \mathrm{C}$ ( $\mathrm{Li}$ et al., 2016). Toluene cracking with Fe supported on silica also showed high hydrogen content compared to other gases such as methane, acetylene, ethylene (Zhang et al., 2018). In this study as well, during the stable toluene conversion period of the $10 \mathrm{~h}$ run (300 to 395 minutes), the main product was hydrogen. The toluene conversions in this study are comparable to studies reported in the literature which include more than $90 \%$ above $750{ }^{\circ} \mathrm{C}$ with biomass char catalyst (Li et al., 2016); more than $85 \%$ conversion with $10 \%$ Fe loading on silica (Zhang et al. 2018); around $95 \%$ conversion at $950{ }^{\circ} \mathrm{C}$ with sewage sludge char as catalyst (Lu et al., 2016); 50-99\% conversion in the temperature range $500-800{ }^{\circ} \mathrm{C}$ with haematite catalyst (Zou et al., 2016); $94 \%$ at $900{ }^{\circ} \mathrm{C}$ with bio char catalyst (Mani et al., 2013); more than 80\% conversion with Ni-Fe bimetallic based supported catalyst at $700{ }^{\circ} \mathrm{C}$ (Laosiripojana et al., 2014)..

In the heating cycle it is observed that hydrogen formation rate is apparent after $700{ }^{\circ} \mathrm{C}$ and at $800{ }^{\circ} \mathrm{C}$ but with time the formation rate decreases. In terms of toluene conversion, complete conversion is obtained only at $800{ }^{\circ} \mathrm{C}$. The maximum hydrogen formation rate is much less than that obtained in the $10 \mathrm{~h}$ run which could be due to insufficient time for complete reduction of iron compounds to iron.

The post reaction sample XRD is shown in Figure 5. The heating cycle sample shows the presence of reduced iron oxides magnetite and wustite, as well as iron. Carbon peaks are not visible in this sample. The $6.75 \mathrm{~h}$ run at $800{ }^{\circ} \mathrm{C}$ shows the presence of iron and carbon in addition to reduced iron oxides. This shows that reaction of toluene to reduce iron oxides and the cracking in the presence of reduced iron to form carbon takes place in parallel. The $10 \mathrm{~h}$ sample which had a carbon content of $46 \%$ shows presence of carbon, iron and iron carbide. During CVD of carbon nano tubes using toluene and ferrocene, presence of iron and iron carbide has been observed (Mierczynski et al., 2017). The iron carbide was due to the reaction between iron and carbon and was attributed to cause the start the formation of carbon nano tubes.

The TGA of carbon containing samples is shown in Figure 6 and the weight loss correlates with the carbon content. The weight loss mostly takes place in the temperature range $550-650{ }^{\circ} \mathrm{C}$ (Figure 6a). The derivative weight curve shows only one peak around $600{ }^{\circ} \mathrm{C}$ (Figure 6b). In a study on CNTs from toluene and ferrocene, the thermal analysis derivative curve showed peaks in the ranges $335-350{ }^{\circ} \mathrm{C}$ and $475-625{ }^{\circ} \mathrm{C}$ (Das et al., 2006). The lower temperature peak was attributed to amorphous carbon and the higher temperature peak to CNT. In this study, the presence of amorphous carbon is not evident in terms of low temperature weight loss. The morphology shows presence of some nano fibers. Thus, this inexpensive waste material shows potential as a catalyst for biomass based hydrogen production as well as nano carbon synthesis.

\section{Conclusions:-}

Red mud showed activity for hydrogen formation from the cracking of toluene. Hydrogen formation rate up to $2 \mathrm{x}$ $10^{-4}$ mole $\min ^{-1} \mathrm{~g}^{-1}$ was obtained at $800{ }^{\circ} \mathrm{C}$. The formation rate reduced due to carbon deposition on the catalyst. The catalyst had up to $46 \%$ carbon in the form of nano fibers. The carbon was in the form of graphite; iron and iron carbide was also present in the sample with high carbon content. Other samples show presence of reduced iron oxides.

\section{Acknowledgement:-}

The authors gratefully acknowledge the British Council for the generous provision of funding through the UKIERI Scheme (Project SA07-19.) 


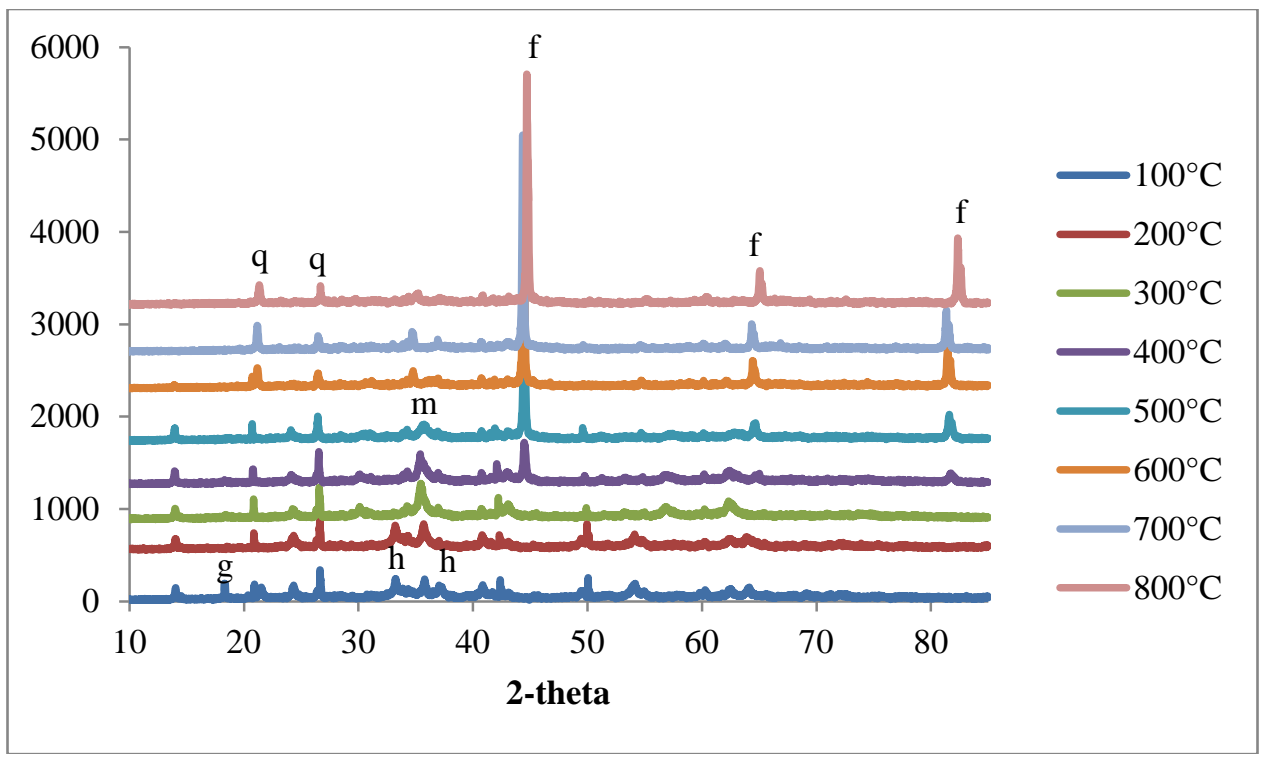

Figure 1:- In-situ XRD of RM7 in 5\% hydrogen (balance nitrogen), g-goethite; h-haematite; m-magnetite; f-iron

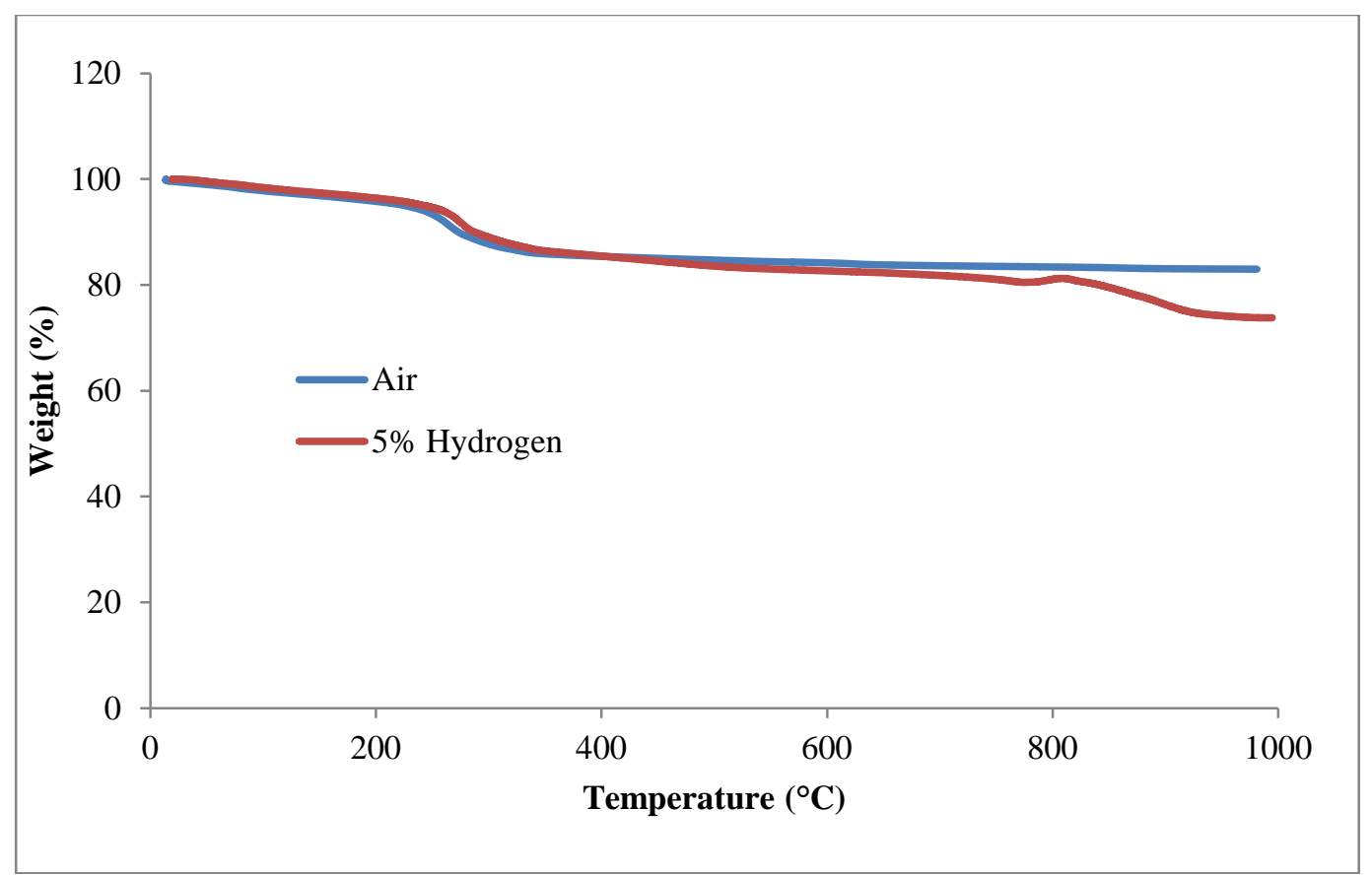

Figure 2:- TGA of RM7 in air and hydrogen 


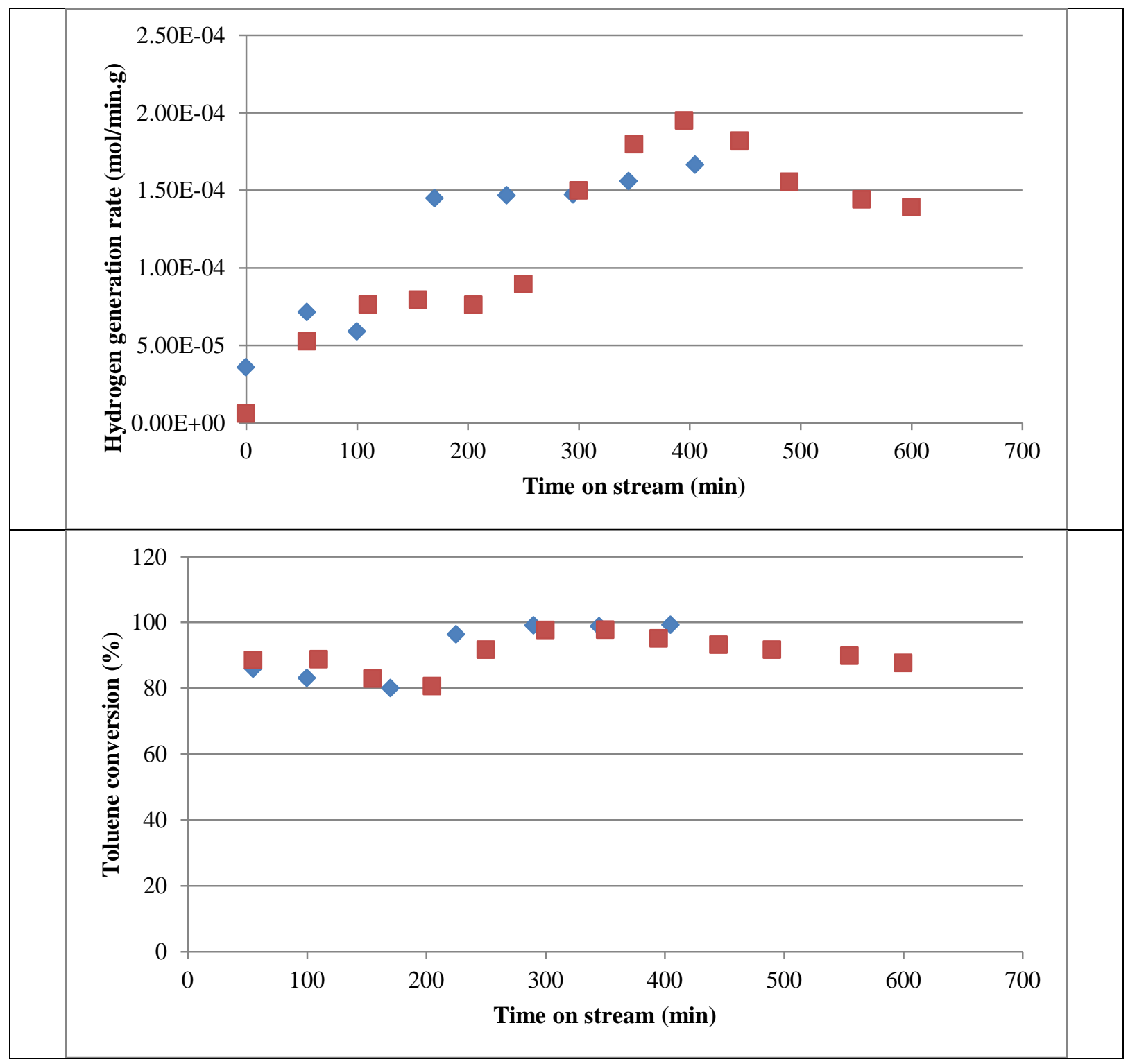

Figure 3:- Hydrogen formation rate and toluene conversion at $800^{\circ} \mathrm{C}$ for $6.75 \mathrm{~h}$ run and $10 \mathrm{~h}$ run

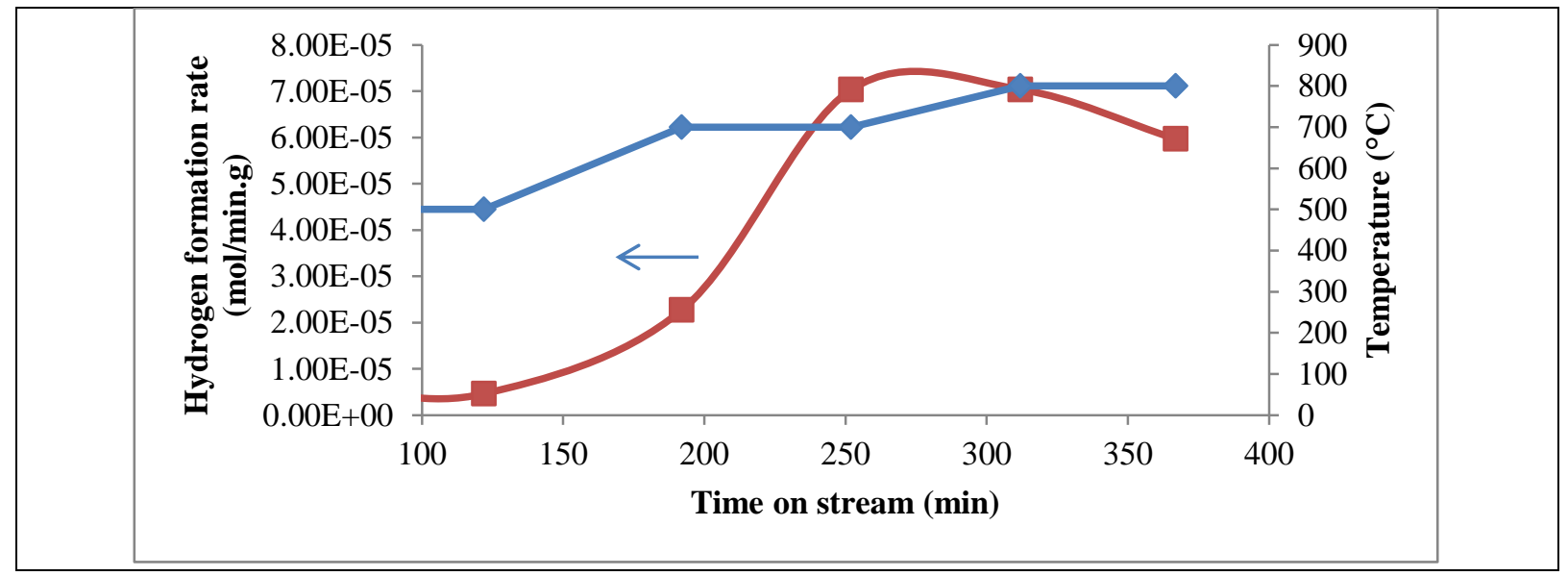




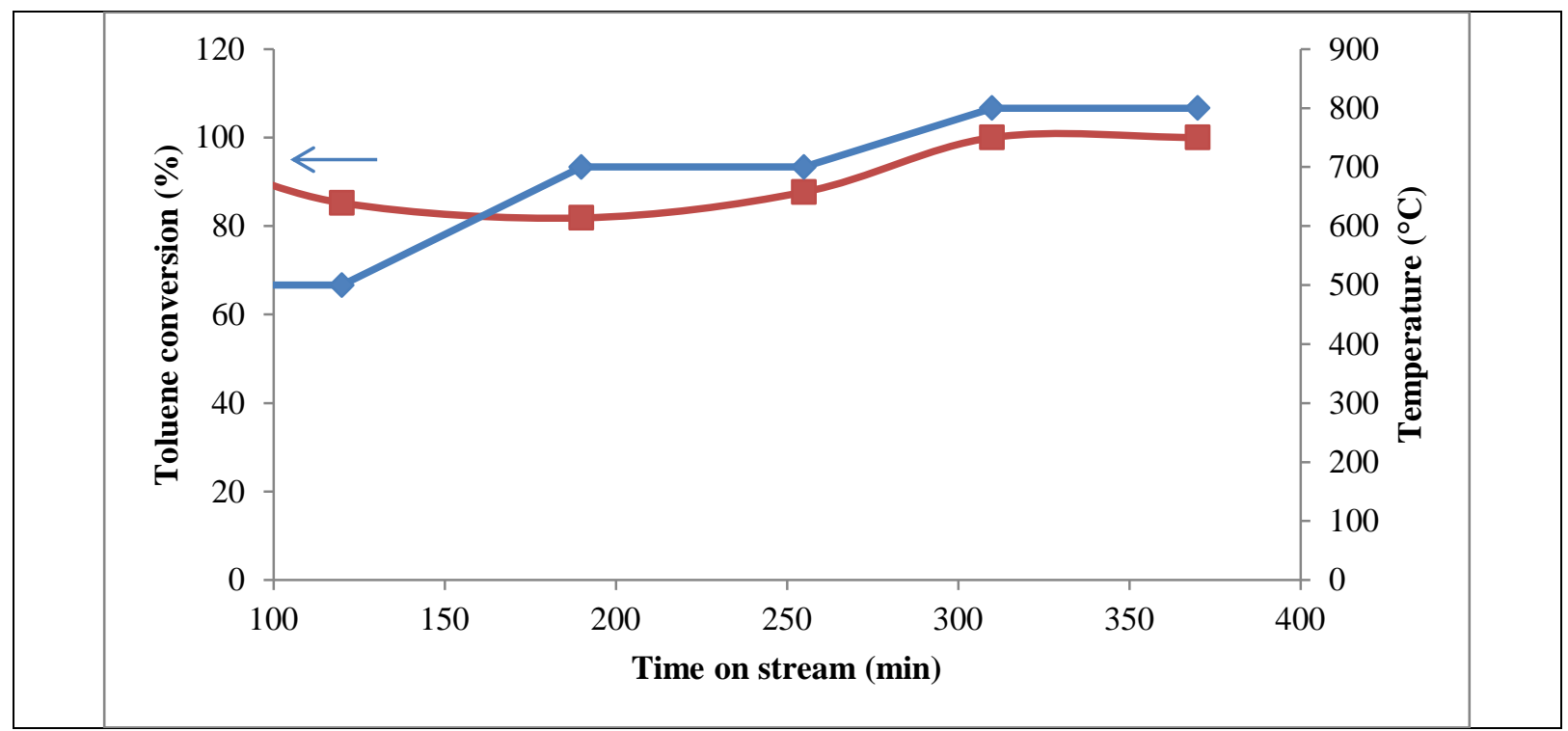

Figure 4:- Hydrogen formation rate and toluene conversion in the heating cycle run

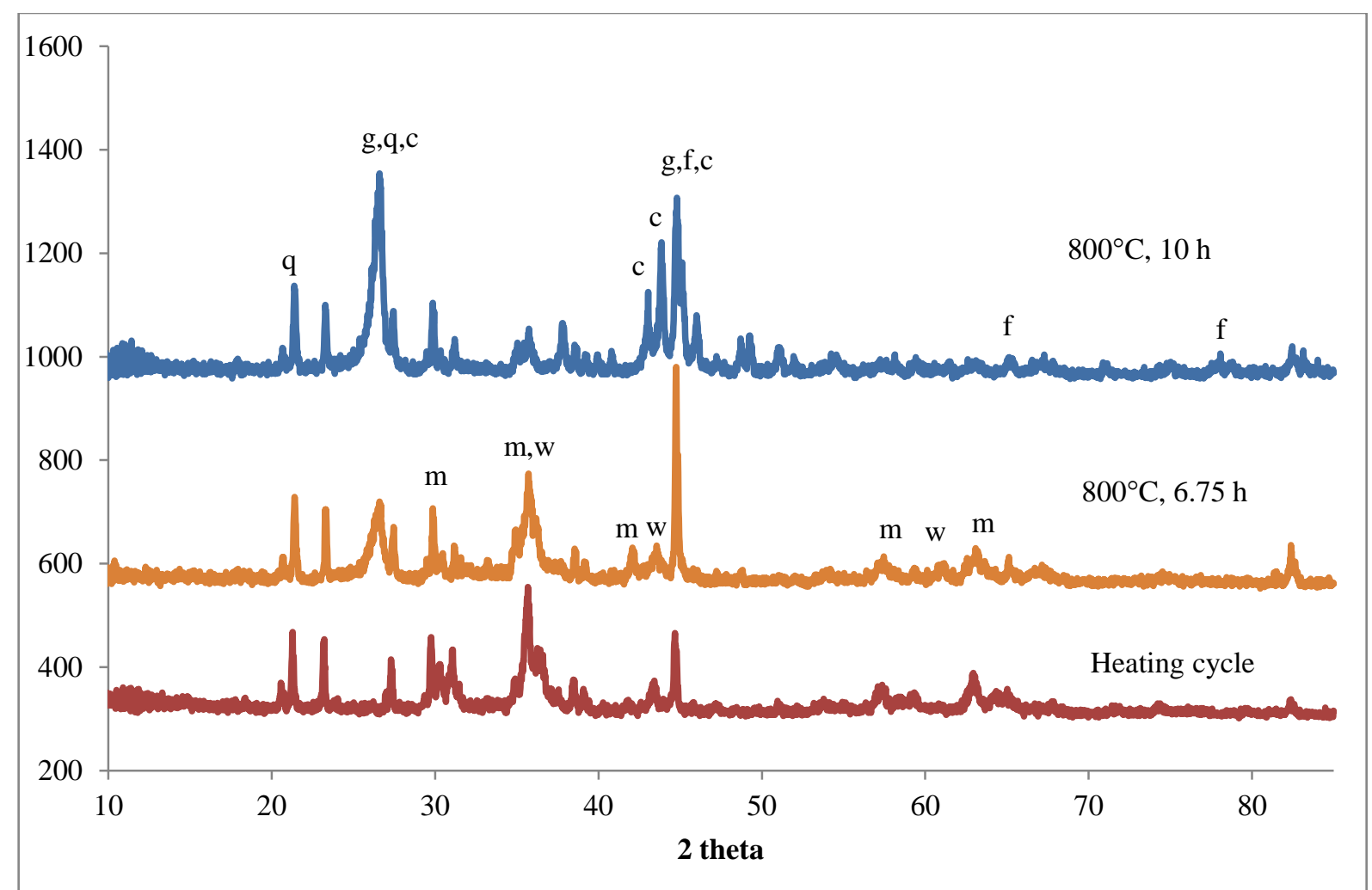

Figure 5:- X-ray diffraction pattern of post reaction catalyst, m-magnetite $\mathrm{Fe}_{3} \mathrm{O}_{4}$, w-wustite $\mathrm{FeO}$, g-cliftonite C, qquartz $\mathrm{SiO}_{2}$, c-iron carbide $\mathrm{Fe}_{3} \mathrm{C}$, f-iron $\mathrm{Fe}$ 


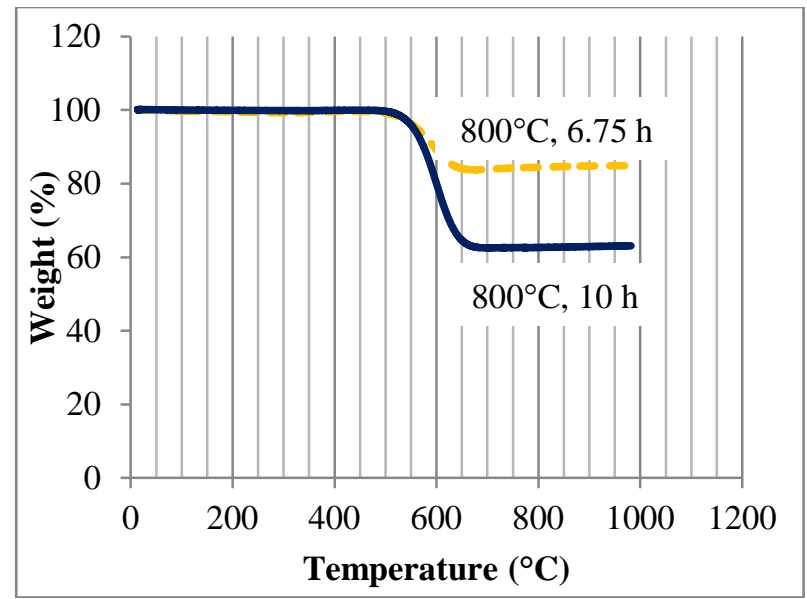

(a)

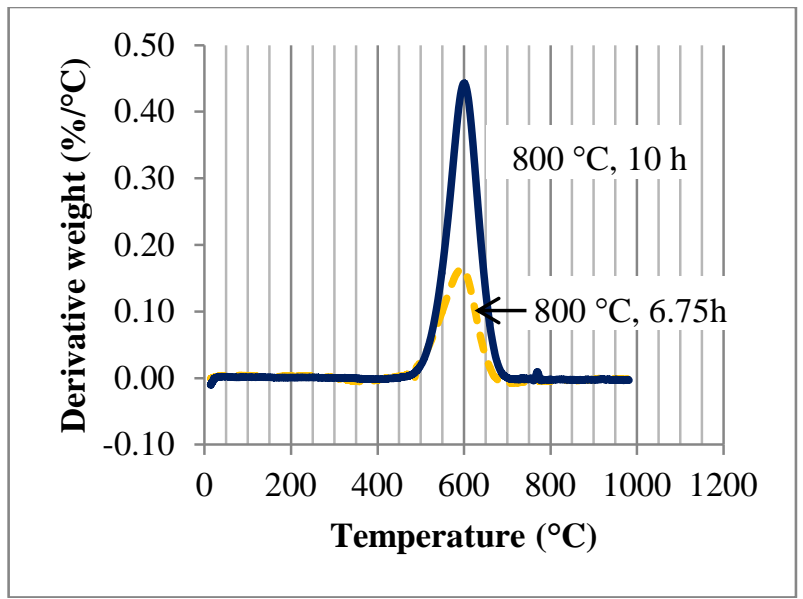

(b)

Figure 6:- TGA profile of post reaction catalyst

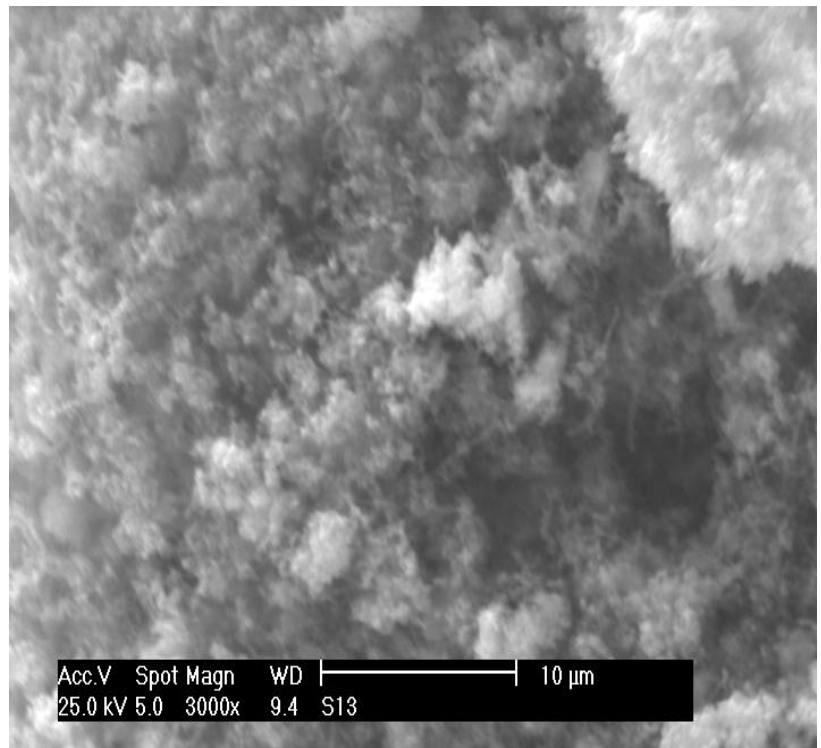

Figure 7:- Scanning electron microscopy of sample exposed to toluene at $800^{\circ} \mathrm{C}$ for $10 \mathrm{~h}$

\section{References:-}

1. Abu El-Rub, Z., Bramer, E. A. and Brem. G. (2004): Review of catalysts for tar elimination in biomass gasification processes. Ind. Eng. Chem. Res., 43(22): 6911-6919.

2. Alharthi, A.I., Hargreaves, J.S.J., Pulford, I.D., Gupta, N., Balakrishnan, M., Batra, V.S. and Singh, R.K. (2016): Hydrocarbon cracking over red mud and modified red mud samples. J. Sustainable Metallurgy, 2(4): 387-393.

3. Balakrishnan. M., Batra. V. S., Hargreaves, J. S. J., Monaghan, A., Pulford, I. D., Rico, J. L. and Sushil, S. (2009): Hydrogen production from methane in the presence of red mud-making mud magnetic. Green Chem., 11(1): 42-47.

4. Baughman, R. H., Zakhidov, A. A. and De Heer, W. A. (2002): Carbon nanotubes-the route toward applications. Science, 297(5582): 787-792.

5. Costa, R. C., Moura, F. C., Oliveira, P. E., Magalhães, F., Ardisson, J. D. and Lago, R. M. (2002): Controlled reduction of red mud waste to produce active systems for environmental applications: heterogeneous Fenton reaction and reduction of $\mathrm{Cr}(\mathrm{VI})$. Chemosphere, 78(9): 1116-20.

6. Das, N., Dalai, A., Mohammadzadeh, J.S. and Adjaye, J. (2006): The effect of feedstock and process conditions on the synthesis of high purity CNTs from aromatic hydrocarbons. Carbon, 44(11): 2236-45. 
7. Gerber, M. A. (2007): Review of novel catalysts for biomass tar cracking and methane reforming (No. PNNL16950). Pacific Northwest National Laboratory (PNNL), Richland, WA (US)

8. Han, J. and Kim, H. (2008): The reduction and control technology of tar during biomass gasification/pyrolysis: an overview. Renewable Sustainable Energy Rev., 12(2): 397-416.

9. Kastner, J. R., Mani, S. and Juneja, A. (2015): Catalytic decomposition of tar using iron supported biochar. Fuel Process. Technol., 130: 31-37.

10. Laosiripojana, N., Sutthisripok, W., Charojrochkul, S. and Assabumrungrat, S. (2014): Development of Ni-Fe bimetallic based catalysts for biomass tar cracking/reforming: Effects of catalyst support and co-fed reactants on tar conversion characteristics. Fuel Process. Technol., 127: 26-32.

11. Li, L., Song, Z., Zhao, X., Ma, C., Kong, X. and Wang, F. (2016): Microwave-induced cracking and $\mathrm{CO}_{2}$ reforming of toluene on biomass derived char. Chem. Eng. J., 284: 1308-1316.

12. Lu, P., Qian, X., Huang, Q., Chi, Y. and Yan, J. (2016): Catalytic cracking of toluene as a tar model compound using sewage-sludge-derived char. Energy Fuels, 30(10): 8327-8334.

13. Mani, S., Kastner, J. R. and Juneja, A. (2013): Catalytic decomposition of toluene using a biomass derived catalyst. Fuel Process. Technol. 114: 118-25.

14. Mierczynski, P., Shtyka, O., Kozanecki, M., Filipczak, P., Maniukiewicz, W., Gromov, D. G., Dubkov, S. V., Sysa, A. V., Trifonov, A. Y., Czylkowska, A. and Szynkowska, M. I. (2017): Effect of the AACVD based synthesis atmosphere on the structural properties of multi-walled carbon nanotubes. Arabian J. Chem., doi.org/10.1016/j.arabjc.2017.08.001

15. Ni, M., Leung, D. Y., Leung, M. K. and Sumathy, K. (2006): An overview of hydrogen production from biomass. Fuel Process. Technol., 87(5):461-472.

16. Pinault, M., Mayne-L'Hermite, M., Reynaud, C., Pichot, V., Launois, P. and Ballutaud, D. (2005): Growth of multiwalled carbon nanotubes during the initial stages of aerosol-assisted CCVD. Carbon, 43(14): 2968-2976.

17. Rios, M. L., González, A. M., Lora, E. E. and del Olmo, O. A. (2018): Reduction of tar generated during biomass gasification: A review. Biomass Bioenergy, 108: 345-70.

18. Samouhos, M., Taxiarchou, M., Pilatos, G., Tsakiridis, P. E., Devlin, E. and Pissas, M. (2017): Controlled reduction of red mud by $\mathrm{H}_{2}$ followed by magnetic separation. Miner. Eng. 105: 36-43.

19. Shen, Y. and Yoshikawa, K. (2013): Recent progresses in catalytic tar elimination during biomass gasification or pyrolysis-A review. Renewable Sustainable Energy Rev. 21: 371-92.

20. Singh, C., Shaffer, M. S., Koziol, K. K., Kinloch, I. A. and Windle, A. H. (2003): Towards the production of large-scale aligned carbon nanotubes. Chem. Phys. Lett., 372(5-6): 860-865.

21. Singh, C., Shaffer, M. S. and Windle, A. H. (2003): Production of controlled architectures of aligned carbon nanotubes by an injection chemical vapour deposition method. Carbon, 41(2): 359-368.

22. Xu, C. C., Donald, J., Byambajav, E. and Ohtsuka, Y. (2010): Recent advances in catalysts for hot-gas removal of tar and $\mathrm{NH}_{3}$ from biomass gasification. Fuel, 89(8): 1784-95.

23. Zhang, Y., Song, Z., Yan, Y., Zhao, X., Sun, J., Mao, Y. and Wang, W. (2018): Performance of Fe/SiC catalysts for cracking of toluene under microwave irradiation. Int. J. Hydrogen Energy, 43(15): 7227-7236.

24. Zou, X., Chen, T., Liu, H., Zhang, P., Chen, D. and Zhu, C. (2016): Catalytic cracking of toluene over hematite derived from thermally treated natural limonite. Fuel, 177: 180-9. 